ARTICLE INFO

Received 22 April 2020

Accepted 21 May 2020

Available online June 2020

\title{
THREE SERIES IONS OF PERFLUOROTRIBUTYLAMINE MASS-SPECTRUM (PFTBA)
}

\author{
N.D. Kagramanov \\ A. N. Nesmeyanov Institute of Organoelement Compounds, Russian Academy of Sciences, 119991, \\ GSP-1, Moscow, B-334, Vavilov St. 28 \\ e-mail:ndkagram@gmail.com
}

\begin{abstract}
The spectral analysis of perfluorotributylamine identified three main series of ions, that are generated during the fragmentation of PFTBA molecular cation radicals, as well as the three subseries formed as a result of additional, symmetrical, stabilizing detachments of fluorine atoms

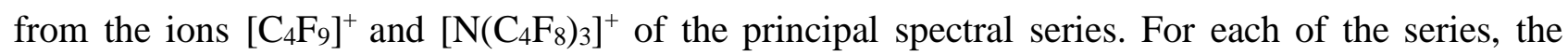
sequence of $\mathrm{F}$ and groups of $\mathrm{CF}_{2}$ detachments correspond to the sequence of mass numbers of generated ions. Using the PFTBA spectrum as an example, the validity and flexibility of earlier proposed algorithm is confirmed for the fragmentation of n-perfluoroalkanes.
\end{abstract}

Keywords: fragmentation algorithm, mass spectrum of perfluorotributylamine, PFTBA, n-perfluoroalkanes, molecular radical cation, series of ions.

\section{Introduction}

Perfluorotributylamine (PFTBA) is the standard for the tuning of mass spectrometers with a mass range of up to 1000 amu based on reference peaks [1,2]. Perhaps, for this reason its massspectrum (NIST \#: 66003 ID \#: 8854 DB: replib Contributer: G.W.A. MILNE, NAT'L INSTITUTES OF HEALTH, USA) is the most high-quality and detailed, of all the spectra of tertiary perfluoramines presented in the NIST libraries.

In contrast to the publications on spectra of amines and tertiary amines [3,4], the detailed analysis of the unique PFTBA spectrum, apparently was not performed. Thus, it was of the utmost interest, to verify the applicability of fragmentation algorithm proposed earlier for nperfluoroalkanes [5], using PFTBA as an example.

In the spectra of n-perfluoroalkanes, the alkyl $\left[\mathrm{C}_{n} \mathrm{~F}_{2 n+1}\right]^{+}$series appears as a result of initial detachment of fluorine atom from $\mathrm{CF}_{3}$ group and subsequent emissions of $\mathrm{CF}_{2}$. A less intense 
alkenyl $\left[\mathrm{C}_{\mathrm{n}} \mathrm{F}_{2 \mathrm{n}-2}\right]^{+}$series begins with the three consecutive detachments of a fluorine atom (M-57). The emission of first fluorine atom occurs as in alkyl series, with the addition of the two symmetrical detachments of a fluorine atom from the opposite terminal group $\mathrm{C}_{2} \mathrm{~F}_{5}$ with the formation of a stabilizing vinyl group.

In comparison to the spectra of n-perfluoroalkanes, PFTBA spectrum with a central nitrogen atom, fixing the end groups of $\mathrm{CF}_{2}$, is interesting for the occurring changes in fragmentation. PFTBA spectrum analysis, conducted using the n-perfluoroalkane algorithm [5], made it possible to isolate the three main series of ions within its spectrum, in addition to three additional subseries formed as a result of symmetric detachments of fluorine atoms from the terminal group $\mathrm{C}_{2} \mathrm{~F}_{5}$ of the $\left[\mathrm{C}_{4} \mathrm{~F}_{9}\right]^{+}$ion, as well as from the $\mathrm{C}_{2} \mathrm{~F}_{4}$ groups of the $\left[\mathrm{N}\left(\mathrm{C}_{4} \mathrm{~F}_{8}\right)_{3}\right]^{+}$ion adjacent to the nitrogen atom, and to confirm the sequences of the decay paths and the applicability of the algorithm, proposed previously for fragmentation of n-perfluoroalkanes.

\section{Fragmentation of PFTBA}

The two main series of ions, achieve maximum peak intensities in the total ion current of PFTBA spectrum are formed during the detachments of $\left(\mathrm{C}_{4} \mathrm{~F}_{9}\right)_{2}{ }^{\mathrm{N}} \mathrm{N} \cdot \alpha-\mathrm{CF}_{2}$ and $\left(\mathrm{C}_{4} \mathrm{~F}_{9}\right)_{2}{ }^{:} \mathrm{N}-\mathrm{CF}_{2} \cdot \beta-$ $\mathrm{CF}_{2} \sigma$-bonds of the central group of PFTBA atoms.

$$
\begin{array}{llllll}
\mathrm{M}-\mathrm{e} \rightarrow & \mathrm{C}_{4} \mathrm{~F}_{9}{ }^{+} \cdot \mathrm{N}\left(\mathrm{C}_{4} \mathrm{~F}_{9}\right)_{2} & \rightarrow & \mathrm{C}_{4} \mathrm{~F}_{9}{ }^{+}+ & \mathrm{N}_{\left(\mathrm{C}_{4} \mathrm{~F}_{9}\right)_{2}} & \mathrm{~m}=452 \\
\mathrm{M}-\mathrm{e} \rightarrow & \mathrm{C}_{3} \mathrm{~F}_{7} \cdot{ }^{+} \mathrm{CF}_{2} \mathrm{~N}\left(\mathrm{C}_{4} \mathrm{~F}_{9}\right)_{2} & \rightarrow & { }^{+} \mathrm{CF}_{2} \mathrm{~N}\left(\mathrm{C}_{4} \mathrm{~F}_{9}\right)_{2}+ & \mathrm{C}_{3} \mathrm{~F}_{7} & \mathrm{~m}=169
\end{array}
$$

As judged by the values of the total ion current of the spectrum, the probabilities of formation of these two series are correlated as 4:1.

$$
\mathbf{N}\left(\mathbf{C}_{\mathbf{4}} \mathbf{F}_{\mathbf{9}}\right)_{3} \quad \mathrm{MW}=671 \quad\left(\text { series } \mathbf{M}-\cdot \mathbf{N}\left(\mathbf{C}_{\mathbf{4}} \mathbf{F}_{\mathbf{9}}\right)_{2}\right) \quad \mathrm{N} 1
$$

detachmnet of nitrogen radical with two substituents

(strongest alkyl-olefin series)

\begin{tabular}{|l|l|l|l|l|}
\hline 671 & $\mathrm{M}-\mathrm{N}\left(\mathrm{C}_{4} \mathrm{~F}_{9}\right)_{2}$ & $=219$ & {$\left[\mathrm{C}_{4} \mathrm{~F}_{9}\right]^{+}$} & $66,6 \%$ \\
\hline 219 & $-\mathrm{CF}_{2}$ & $=169$ & {$\left[\mathrm{C}_{3} \mathrm{~F}_{7}\right]^{+}$} & $3,9 \%$ \\
\hline$* 169$ & $-\mathrm{F}$ & $=150$ & {$\left[\mathrm{C}_{3} \mathrm{~F}_{6}\right]^{+}$} & $2,4 \%$ \\
\hline 219 & $-\mathrm{CF}_{2}$ & $=119$ & {$\left[\mathrm{C}_{2} \mathrm{~F}_{5}\right]^{+}$} & $11,0 \%$ \\
\hline$* 119$ & $-\mathrm{F}$ & {$\left[\mathrm{C}_{2} \mathrm{~F}_{4}\right]^{+}$} & $13,5 \%$ \\
\hline 119 & $-\mathrm{CF}_{2}$ & $=69$ & {$\left[\mathrm{CF}_{3}\right]^{+}$} & $100 \%$ \\
\hline & \multicolumn{3}{|r|}{$\begin{array}{r}\text { Ion current series: } 197,4 \% \\
\end{array}$} & $(46.90 \%$ of total ion current of the spectrum $)$ \\
\hline
\end{tabular}


As a result of two stabilizing detachments $\mathrm{F}$, two olefin ions: $169 *\left[\mathrm{C}_{3} \mathrm{~F}_{6}\right]^{+}$and $119 *$ $\left[\mathrm{C}_{2} \mathrm{~F}_{4}\right]^{+}$, are formed within the N1 series, that consists out of four alkyl ions.

The series of perfluoroalkyl ions $\mathrm{N} 1$ are accompanied by the alkenyl subseries $\mathrm{N} 1 *$, the probability of which is 1.8 less than the probability of the main series.

The alkenyl subseries $\mathrm{N} 1 *$ differs from the main series $\mathrm{N} 1$ by the additional, symmetrical and stabilizing detachment of two fluorine atoms from terminal $\mathrm{C}_{2} \mathrm{~F}_{5}$ group, with the formation of vinyl group $\left[\mathrm{CF}_{2}=\mathrm{CF}_{2}-\mathrm{CF}_{2}-\mathrm{CF}_{2}\right]^{+}$. The resulting $\left[\mathrm{C}_{4} \mathrm{~F}_{9}\right]^{+}$ion, the $\mathrm{N} 1$ series of fragmented alkyl ions, and alkenyl subseries N1* completely repeat the fragmentation of linear perfluoroalkanes [5].

$$
\mathbf{N}\left(\mathbf{C}_{\mathbf{4}} \mathbf{F}_{\mathbf{9}}\right)_{3} \quad \mathrm{MW}=671 \quad\left(\text { subseries } \mathrm{M}-\cdot \mathbf{N}\left(\mathbf{C}_{\mathbf{4}} \mathbf{F}_{\mathbf{9}}\right)_{\mathbf{2}}-\mathbf{- 2} \mathbf{F}\right) \quad \mathrm{N} 1^{*}
$$

detachment of nitrogen radical with two substituents and two fluorine atoms

(the alkyl series N1 and the alkenyl subseries N1 * have a common ion with m/z 219)

\begin{tabular}{|c|c|c|c|c|c|}
\hline 671 & $\mathrm{M}-\mathrm{N}\left(\mathrm{C}_{4} \mathrm{~F}_{9}\right)_{2}$ & $=219$ & {$\left[\mathrm{CF}_{3}-\mathrm{CF}_{2}-\mathrm{CF}_{2}-\mathrm{CF}_{2}\right]^{+}$} & 219 & $66,6 \%$ \\
\hline 219 & $-2 \cdot F$ & $=181$ & {$\left[\mathrm{CF}_{2}=\mathrm{CF}-\mathrm{CF}_{2}-\mathrm{CF}_{2}\right]^{+}$} & 181 & $3,1 \%$ \\
\hline 181 & $-\mathrm{CF}_{2}$ & $=131$ & {$\left[\mathrm{CF}_{2}=\mathrm{CF}-\mathrm{CF}_{2}\right]^{+}$} & 131 & $41,6 \%$ \\
\hline 131 & $-\mathrm{CF}_{2}$ & $=81$ & {$\left[\mathrm{CF}_{2}=\mathrm{CF}\right]^{+}$} & 81 & $0,4 \%$ \\
\hline
\end{tabular}

The second main (third in intensity) series of ion peaks is formed during the separation of ${ }^{+} \cdot[\mathrm{M}]-\mathrm{C}_{3} \mathrm{~F}_{7}=\left[\mathrm{CF}_{2} \mathrm{~N}\left(\mathrm{C}_{4} \mathrm{~F}_{9}\right)_{2}\right]^{+} 50211,4 \%$ radical, and subsequent detachments of two fluorine atoms from two terminal groups of $\mathrm{CF}_{3}$ perfluoroalkyl substituents, and seven emissions of $\mathrm{CF}_{2}$ groups.

\section{$\mathbf{N}\left(\mathbf{C}_{\mathbf{4}} \mathbf{F}_{\mathbf{9}}\right)_{\mathbf{3}} \quad \mathrm{MW}=671 \quad\left(\right.$ series $\left.\mathbf{M}-\mathbf{C}_{\mathbf{3}} \mathbf{F}_{\mathbf{7}}-\mathbf{- 2} \cdot \mathbf{F}\right) \mathrm{N} 2$}

detachment of perfluoroalkyl radical $\mathrm{C}_{4} \mathrm{~F}_{9}$ without one $\mathrm{CF}_{2}$ group, two fluorine atoms from two groups of $\mathrm{CF}_{3}$ and the carbene "leaf fall" of seven $\mathrm{CF}_{2}$ groups

(alkyl nitrogen-containing series N2, and series N3 M-3F have a common ion with $\mathrm{m} / \mathrm{z} 464$ )

\begin{tabular}{|l|l|l|l|l|}
\hline 671 & $\mathrm{M}-\mathrm{C}_{3} \mathrm{~F}_{7}$ & $=502$ & {$\left[\mathrm{CF}_{2}-\mathrm{N}-\left(\mathrm{C}_{4} \mathrm{~F}_{9}\right)_{2}\right]^{+}$} & $11,4 \%$ \\
\hline 502 & $-2 \cdot \mathrm{F}$ & $=464$ & {$\left[\mathrm{CF}_{2}-\mathrm{N}-\left(\mathrm{C}_{4} \mathrm{~F}_{8}\right)_{2}\right]^{+}$} & $6,4 \%$ \\
\hline$* 464$ & $-\mathrm{CF}_{2}$ & $=414$ & {$\left[\mathrm{CF}_{2}-\mathrm{N}\left(\mathrm{C}_{3} \mathrm{~F}_{6}\right)\left(\mathrm{C}_{4} \mathrm{~F}_{8}\right)\right]^{+}$} & $7,0 \%$ \\
\hline 414 & $-\mathrm{CF}_{2}$ & $=364$ & {$\left[\mathrm{CF}_{2}-\mathrm{N}-\left(\mathrm{C}_{3} \mathrm{~F}_{6}\right)_{2}\right]^{+}$} & $0,6 \%$ \\
\hline 364 & $-\mathrm{CF}_{2}$ & $=314$ & {$\left[\mathrm{CF}_{2}-\mathrm{N}-\left(\mathrm{C}_{2} \mathrm{~F}_{4}\right)\left(\mathrm{C}_{3} \mathrm{~F}_{6}\right)\right]^{+}$} & $1,0 \%$ \\
\hline 314 & $-\mathrm{CF}_{2}$ & $=264$ & {$\left[\mathrm{CF}_{2}-\mathrm{N}-\left(\mathrm{C}_{2} \mathrm{~F}_{4}\right)_{2}\right]^{+}$} & $15,2 \%$ \\
\hline
\end{tabular}




\begin{tabular}{|l|l|l|l|l|}
\hline 264 & $-\mathrm{CF}_{2}$ & $=214$ & {$\left[\left(\mathrm{CF}_{2}\right)_{2} \mathrm{~N}_{-}-\mathrm{C}_{2} \mathrm{~F}_{4}\right]^{+}$} & $1,2 \%$ \\
\hline 214 & $-\mathrm{CF}_{2}$ & $=164$ & {$\left[\left(\mathrm{CF}_{2}\right)_{3} \mathrm{~N}\right]^{+}$} & $1,2 \%$ \\
\hline 164 & $-\mathrm{CF}_{2}$ & $=114$ & {$\left[\mathrm{CF}_{2}-\mathrm{N}_{-}-\mathrm{CF}_{2}\right]^{+}$} & $4,1 \%$ \\
\hline \multicolumn{4}{|r}{$\quad \begin{array}{r}\text { Ion current series } 48,1 \% \\
(11,42 \% \text { of total ion current in the spectrum })\end{array}$} \\
\hline
\end{tabular}

The least intense main series of PFTBA spectrum is the N3 series, which occurs when three fluorine atoms are detached from three terminal $\mathrm{CF}_{3}$ groups of three substituents. The detachment of one fluorine atom from one of $\mathrm{CF}_{3}$ groups, apparently, initiates the symmetrical detachments of two fluorine atoms from two other $\mathrm{CF}_{3}$ groups. The probability of the formation of this series is 4.7 times less than the probability of the main series N1.

$$
\left.\mathbf{N}\left(\mathbf{C}_{\mathbf{4}} \mathbf{F}_{\mathbf{9}}\right)_{3} \quad \text { MW=671 (series } \mathbf{M}-\mathbf{3} \mathbf{3}\right) \quad \text { N3 }
$$

nitrogen-containing alkyl series

(separation of three fluorine atoms from three end groups of $\mathrm{CF}_{3}$ of three substituents and the carbene "leaf fall" of ten $\mathrm{CF}_{2}$ groups)

\begin{tabular}{|c|c|c|c|c|}
\hline 671 & $(\mathrm{M}-3 \cdot \mathrm{F})$ & $=614$ & {$\left[\mathrm{~N}\left(\mathrm{C}_{4} \mathrm{~F}_{8}\right)_{3}\right]^{+}$} & $4,1 \%$ \\
\hline 614 & $-\mathrm{CF}_{2}$ & $=564$ & {$\left[\left(\mathrm{C}_{3} \mathrm{~F}_{6}\right)-\mathrm{N}\left(\mathrm{C}_{4} \mathrm{~F}_{8}\right)_{2}\right]^{+}$} & $0,4 \%$ \\
\hline 564 & $-\mathrm{CF}_{2}$ & $=514$ & {$\left[\left(\mathrm{C}_{3} \mathrm{~F}_{6}\right)_{2} \mathrm{~N}-\mathrm{C}_{4} \mathrm{~F}_{8}\right]^{+}$} & $0,4 \%$ \\
\hline 514 & $-\mathrm{CF}_{2}$ & $=464$ & {$\left[\mathrm{~N}\left(\mathrm{C}_{3} \mathrm{~F}_{6}\right)_{3}\right]^{+}$} & $6,4 \%$ \\
\hline$* 464$ & $-\mathrm{CF}_{2}$ & $=414$ & {$\left[\mathrm{C}_{2} \mathrm{~F}_{4}-\mathrm{N}\left(\mathrm{C}_{3} \mathrm{~F}_{6}\right)_{2}\right]^{+}$} & $7,0 \%$ \\
\hline 414 & $-\mathrm{CF}_{2}$ & $=364$ & {$\left[\left(\mathrm{C}_{2} \mathrm{~F}_{4}\right)_{2} \mathrm{~N}-\mathrm{C}_{3} \mathrm{~F}_{6}\right]^{+}$} & $0,6 \%$ \\
\hline 364 & $-\mathrm{CF}_{2}$ & $=314$ & {$\left[\mathrm{~N}\left(\mathrm{C}_{2} \mathrm{~F}_{4}\right)_{3}\right]^{+}$} & $1,0 \%$ \\
\hline 314 & $-\mathrm{CF}_{2}$ & $=264$ & {$\left[\left(\mathrm{C}_{2} \mathrm{~F}_{4}\right)_{2} \mathrm{~N}-\mathrm{CF}_{2}\right]^{+}$} & $15,2 \%$ \\
\hline 264 & $-\mathrm{CF}_{2}$ & $=214$ & {$\left[\left(\mathrm{CF}_{2}\right)_{2} \mathrm{~N}-\mathrm{C}_{2} \mathrm{~F}_{4}\right]^{+}$} & $1,2 \%$ \\
\hline 214 & $-\mathrm{CF}_{2}$ & $=164$ & {$\left[\left(\mathrm{CF}_{2}\right)_{3} \mathrm{~N}\right]^{+}$} & $1,2 \%$ \\
\hline 164 & $-\mathrm{CF}_{2}$ & $=114$ & {$\left[\mathrm{CF}_{2}-\mathrm{N}_{-} \mathrm{CF}_{2}\right]^{+}$} & $4,1 \%$ \\
\hline
\end{tabular}

Series N ${ }^{+} \cdot[\mathrm{M}]-3 \cdot \mathrm{F} \quad 4.1 \%$ is accompanied by two concomitant alkenyl subseries N3* and $\mathrm{N} 3 * *$, formed as a result of additional stabilizing detachments of two fluorine atoms from group $\mathrm{CF}_{2}-\mathrm{CF}_{2}-\mathrm{N}$ of an adjacent nitrogen atom, one of substituents and, accordingly, the detachment of four fluorine atoms from two groups $\mathrm{CF}_{2}-\mathrm{CF}_{2}-\mathrm{N}$ of two substituents of $\left[\mathrm{N}\left(\mathrm{C}_{4} \mathrm{~F}_{8}\right)_{3}\right]^{+}$ion, adjacent to the nitrogen. 
The intensities and probabilities of these two alkenyl subseries are 2.9 and 5.2 times less than the intensities of the series ${ }^{+}[\mathrm{M}]-3 \cdot \mathrm{F}$.

The detachment of first fluorine atom from the $\alpha-\mathrm{CF}_{2} \mathrm{~N}$ substituent group, probably initiates the stabilizing detachment of second fluorine atom from the $\beta-\mathrm{CF}_{2}$ group.

$$
\mathbf{N}\left(\mathbf{C}_{4} \mathbf{F}_{\mathbf{9}}\right)_{3} \quad \mathrm{MW}=671 \quad(\text { series } \mathrm{M}-\mathbf{5} \cdot \mathbf{F}) \quad \mathrm{N} 3 *
$$

detachment of three fluorine atoms from three terminal groups of $\mathrm{CF}_{3}$, and then - another two

fluorine atoms from adjacent $\mathrm{CF}_{2} \mathrm{CF}_{2}$ group of one of a substituents (nitrogen-containing series N3 and N3* have a common ion with $\mathrm{m} / \mathrm{z} 614$ )

\begin{tabular}{|l|l|l|l|l|}
\hline 671 & $(\mathrm{M}-3 \cdot \mathrm{F})$ & $=614$ & {$\left[\mathrm{~N}\left(\mathrm{C}_{4} \mathrm{~F}_{8}\right)_{3}\right]^{+}$} & $4,1 \%$ \\
\hline 614 & $-2 \cdot \mathrm{F}$ & $=576$ & {$\left[\mathrm{CF}_{2}-\mathrm{CF}_{2}-\mathrm{CF}=\mathrm{CF}-\mathrm{N}\left(\mathrm{C}_{4} \mathrm{~F}_{8}\right)_{2}\right]^{+}$} & $2,0 \%$ \\
\hline 576 & $-\mathrm{CF}_{2}$ & $=526$ & {$\left[\mathrm{CF}{ }_{2}-\mathrm{CF}=\mathrm{CF}-\mathrm{N}\left(\mathrm{C}_{4} \mathrm{~F}_{8}\right)_{2}\right]^{+}$} & $0,4 \%$ \\
\hline 526 & $-\mathrm{CF}_{2}$ & $=476$ & {$\left[\mathrm{CF}=\mathrm{CF}-\mathrm{N}\left(\mathrm{C}_{4} \mathrm{~F}_{8}\right)_{2}\right]^{+}$} & $0,4 \%$ \\
\hline 476 & $-\mathrm{CF}_{2}$ & $=426$ & {$\left[\mathrm{CF}=\mathrm{CF}-\mathrm{N}\left(\mathrm{C}_{3} \mathrm{~F}_{6}\right)\left(\mathrm{C}_{4} \mathrm{~F}_{8}\right)\right]^{+}$} & $2,4 \%$ \\
\hline 426 & $-\mathrm{CF}_{2}$ & $=376$ & {$\left[\mathrm{CF}=\mathrm{CF}-\mathrm{N}\left(\mathrm{C}_{3} \mathrm{~F}_{6}\right)_{2}\right]^{+}$} & $1,4 \%$ \\
\hline 376 & $-\mathrm{CF}_{2}$ & $=326$ & {$\left[\mathrm{CF}=\mathrm{CF}-\mathrm{N}\left(\mathrm{C}_{2} \mathrm{~F}_{4}\right)\left(\mathrm{C}_{3} \mathrm{~F}_{6}\right)\right]^{+}$} & $0,6 \%$ \\
\hline 326 & $-\mathrm{CF}_{2}$ & $=276$ & {$\left[\mathrm{CF}=\mathrm{CF}-\mathrm{N}\left(\mathrm{C}_{2} \mathrm{~F}_{4}\right)_{2}\right]^{+}$} & $0,4 \%$ \\
\hline 276 & $-\mathrm{CF}_{2}$ & $=226$ & {$\left[\mathrm{CF}=\mathrm{CF}-\mathrm{N}\left(\mathrm{CF}_{2}\right)\left(\mathrm{C}_{2} \mathrm{~F}_{4}\right)\right]^{+}$} & $0,6 \%$ \\
\hline 226 & $-\mathrm{CF}_{2}$ & $=176$ & {$\left[\mathrm{CF}=\mathrm{CF}-\mathrm{N}\left(\mathrm{CF}_{2}\right)_{2}\right]^{+}$} & $1,2 \%$ \\
\hline 176 & $-\mathrm{CF}_{2}$ & $=126$ & {$\left[\mathrm{CF}=\mathrm{CF}-\mathrm{N}-\mathrm{CF}_{2}\right]^{+}$} & $0,4 \%$ \\
\hline 126 & $-\mathrm{CF}_{2}$ & $=76$ & {$[\mathrm{CF}=\mathrm{N}=\mathrm{CF}]^{+}$} & $0,4 \%$ \\
\hline & & $(3,39 \%$ of total ion current in the spectrum $)$ \\
\hline
\end{tabular}

$\mathbf{N}\left(\mathbf{C}_{4} \mathbf{F}_{9}\right)_{3} \quad M W=671 \quad($ series $\mathrm{M}-7 \cdot \mathbf{F}) \quad \mathrm{N} 3 * *$

detachment of three fluorine atoms from three terminal $\mathrm{CF}_{3}$ groups of three substituents and two fluorine atoms from each of two $\mathrm{CF}_{2} \mathrm{CF}_{2}$ groups adjacent to the nitrogen atom of two substituents (nitrogen-containing series N3, N3* and N3** have a common ion with $\mathrm{m} / \mathrm{z} 614$ )

\begin{tabular}{|l|l|l|l|l|}
\hline 671 & $(\mathrm{M}-3 \mathrm{~F})$ & $=614$ & {$\left[\mathrm{~N}\left(\mathrm{C}_{4} \mathrm{~F}_{8}\right)_{3}\right]^{+}$} & $4,1 \%$ \\
\hline 614 & $-2 \mathrm{~F}$ & $=576$ & {$\left[\left(\mathrm{CF}_{2}-\mathrm{CF}_{2}-\mathrm{CF}=\mathrm{CF}\right) \mathrm{N}_{\left.\left(\mathrm{C}_{4} \mathrm{~F}_{8}\right)_{2}\right]^{+}}\right.$} & $0,6 \%$ \\
\hline 576 & $-2 \mathrm{~F}$ & $=538$ & {$\left[\left(\mathrm{CF}_{2}-\mathrm{CF}_{2}-\mathrm{CF}=\mathrm{CF}\right)_{2} \mathrm{~N}\left(\mathrm{C}_{4} \mathrm{~F}_{8}\right)\right]^{+}$} & $0,6 \%$ \\
\hline 538 & $-\mathrm{CF}_{2}$ & $=488$ & {$\left[\mathrm{CF}_{2}-\mathrm{CF}=\mathrm{CF}-\mathrm{N}\left(\mathrm{C}_{4} \mathrm{~F}_{8}\right)\left(\mathrm{CF}=\mathrm{CF}-\mathrm{CF}_{2}-\mathrm{CF}_{2}\right)\right]^{+}$} & $0,4 \%$ \\
\hline 488 & $-\mathrm{CF}_{2}$ & $=438$ & {$\left[\left(\mathrm{CF}_{2}-\mathrm{CF}=\mathrm{CF}\right)_{2} \mathrm{~N}_{\left.\left(\mathrm{C}_{4} \mathrm{~F}_{8}\right)\right]^{+}}\right.$} & $0,2 \%$ \\
\hline 438 & $-\mathrm{CF}_{2}$ & $=388$ & {$\left[\mathrm{CF}=\mathrm{CF}-\mathrm{N}\left(\mathrm{C}_{4} \mathrm{~F}_{8}\right)\left(\mathrm{CF}=\mathrm{CF}-\mathrm{CF}_{2}\right)\right]^{+}$} & $0,4 \%$ \\
\hline
\end{tabular}




\begin{tabular}{|l|l|l|l|l|}
\hline 388 & $-\mathrm{CF}_{2}$ & $=338$ & {$\left[(\mathrm{CF}=\mathrm{CF})_{2} \mathrm{~N}\left(\mathrm{C}_{4} \mathrm{~F}_{8}\right)\right]^{+}$} & $0,4 \%$ \\
\hline 338 & $-\mathrm{CF}_{2}$ & $=288$ & {$\left[(\mathrm{CF}=\mathrm{CF})_{2} \mathrm{~N}\left(\mathrm{C}_{3} \mathrm{~F}_{6}\right)\right]^{+}$} & $0,2 \%$ \\
\hline 288 & $-\mathrm{CF}_{2}$ & $=238$ & {$\left[(\mathrm{CF}=\mathrm{CF})_{2} \mathrm{~N}\left(\mathrm{C}_{2} \mathrm{~F}_{4}\right)\right]^{+}$} & $0,2 \%$ \\
\hline 238 & $-\mathrm{CF}_{2}$ & $=188$ & {$\left[(\mathrm{CF}=\mathrm{CF})_{2} \mathrm{~N}\left(\mathrm{CF}_{2}\right)\right]^{+}$} & $0,2 \%$ \\
\hline 188 & $-\mathrm{CF}_{2}$ & $=138$ & {$[\mathrm{CF}=\mathrm{CF}-\mathrm{N}-\mathrm{CF}=\mathrm{CF}]^{+}$} & $0,2 \%$ \\
\hline 138 & $-\mathrm{C}_{2} \mathrm{~F}_{2}$ & $=76$ & {$[\mathrm{CF}=\mathrm{N}=\mathrm{CF}]^{+}$} & $0,4 \%$ \\
\hline \multicolumn{5}{|r}{} \\
\cline { 2 - 2 }
\end{tabular}

A comparison of perfluorotributylamine spectra recorded via a magnetic device and an ion trap device (Polaris Q) (Fig. 1), illustrates the conflict of series 1 and (1* with higher number of detachments), depending on the type of mass-spectrometer. The required conditions for reinforcement of series $1^{*}$ is the higher excitation energy $[\mathrm{M}]^{+}$, and the longer period of fragmentation.

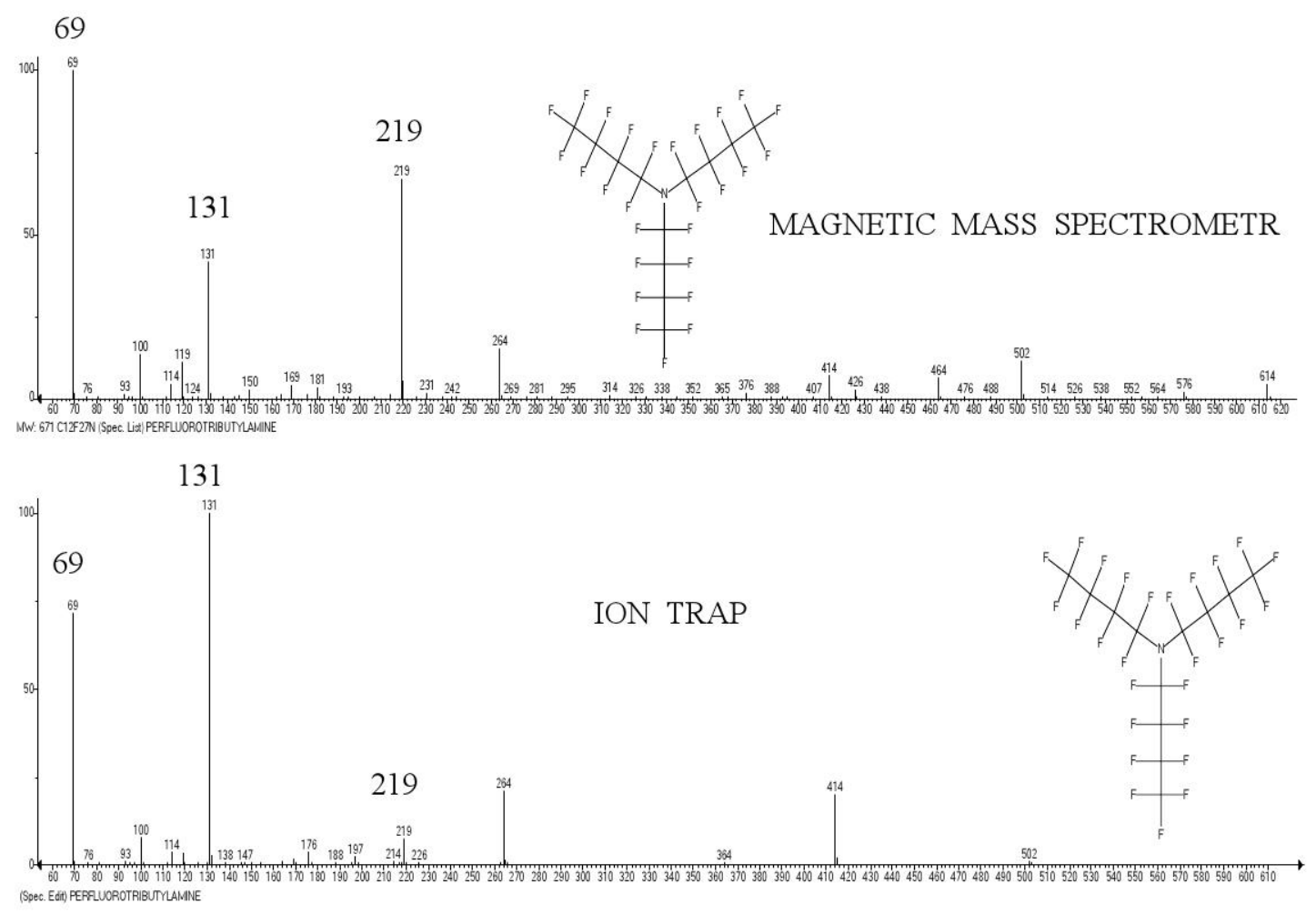

Figure. 1. Spectra of perfluorobutylamine (PFTBA), taken via a magnetic device and an ion trap.

If in the spectrum obtained via a magnetic device the alkyl fragmentation with base ion $\mathrm{CF}_{3}$ is the principal one, then in the conditions of an ion trap, as a result of additional stabilizing 
detachments of fluorine atoms, the alkenyl fragmentation with base ion $\left[\mathrm{CF}=\mathrm{CF}-\mathrm{CF}_{2}\right]^{+} \mathrm{m} / \mathrm{z} 131$ becomes the dominant.

In PFTBA spectrum, as well as in the spectra of n-alkanes and n-perfluoroalkanes [5], taken via devices with ion traps, an alkenyl series of ions is dominant. The reason for this, are the design features of the ion trap.

\section{Conclusions}

The three main series of PFTBA ions, occur during the decay of three concurrently formed molecular ions, with cation-radicals centers on $\left(\mathrm{C}_{4} \mathrm{~F}_{9}\right)_{2} \mathrm{~N}^{+} \mathrm{CF}_{2}-\alpha$, and $\left(\mathrm{C}_{4} \mathrm{~F}_{9}\right)_{2} \mathrm{NCF}_{2}{ }^{+} \mathrm{CF}_{2}-\beta \quad \sigma$-bonds of atoms central group in the molecule, as well as $\sigma$-bonds $\mathrm{F}^{\cdot}{ }^{+} \mathrm{CF}_{2}\left(\mathrm{CF}_{2}\right)_{3} \mathrm{~N}\left(\mathrm{C}_{4} \mathrm{~F}_{9}\right)_{2}$ of one of peripheral groups $\mathrm{CF}_{3}$.

Since the simultaneous detachment of three fluorine atoms from three terminal $\mathrm{CF}_{3}$ groups is unbelievable, we can conclude, that the detachment of one $\mathrm{F}$ atom from one of the $\mathrm{CF}_{3}$ groups initiates symmetrical detachments of two fluorine atoms from the other two groups.

The relative probabilities of PFTBA fragmentation pathways, presented in Table 1, correspond to the total ion current values of the three main series N1-3 and the three subseries N1*, $\mathrm{N} 3 *$, and $3 * *$.

Table 1. The ion current of PFTBA series, the relative probability of their formation, the total number of detachments, the total detached mass and the mass of final recorded ion.

\begin{tabular}{|l|l|l|l|l|l|l|}
\hline N series & $\mathrm{N} 1$ & $\mathrm{~N} 1 *$ & $\mathrm{~N} 2$ & $\mathrm{~N} 3$ & $\mathrm{~N} 3 *$ & $\mathrm{~N} 3 * *$ \\
\hline $\begin{array}{l}\text { Ion series } \\
\text { current, } \%\end{array}$ & 46,9 & 26,5 & 11,4 & 9,9 & 3,4 & 1,9 \\
\hline $\begin{array}{l}\text { Relates series } \\
\text { probabilities }\end{array}$ & 25,1 & 14,2 & 6,1 & 5,3 & 1,8 & 1,0 \\
\hline $\begin{array}{l}\sum \text { Number of } \\
\text { breaks }\end{array}$ & 4 & 5 & 10 & 13 & 15 & 16 \\
\hline$\sum$ Tear off mass & 602 & 590 & 557 & 557 & 595 & 595 \\
\hline $\begin{array}{l}\text { Mass of the final } \\
\text { ion }\end{array}$ & $\begin{array}{l}69 \\
{[\mathrm{CF}]^{+}}\end{array}$ & $\begin{array}{l}81 \\
{\left[\mathrm{CF}_{2}=\mathrm{CF}\right]^{+}}\end{array}$ & $\begin{array}{l}114 \\
{\left[\mathrm{~N}\left(\mathrm{CF}_{2}\right)_{2}\right]^{+}}\end{array}$ & $\begin{array}{l}114 \\
{\left[\mathrm{~N}\left(\mathrm{CF}_{2}\right)_{2}\right]^{+}}\end{array}$ & $\begin{array}{l}76 \\
{[\mathrm{CF}=\mathrm{N}=\mathrm{CF}]^{+}}\end{array}$ & $\begin{array}{l}76 \\
{[\mathrm{CF}=\mathrm{N}=\mathrm{CF}]^{+}}\end{array}$ \\
\hline
\end{tabular}

In series N1, four radical detachments lead to the formation of alkyl ions, and two additional detachments lead to the formation of olefin ions $\left[\mathrm{C}_{3} \mathrm{~F}_{6}\right]^{+}$and $\left[\mathrm{C}_{2} \mathrm{~F}_{4}\right]^{+}$.

As it can be seen from Table 1, the relative probabilities of series formation decreases in proportion to increase in the number of breaks occurring. 
In comparison to the other series with the minimal number of detachments, the required condition for formation of series with maximal number of detachments, is the maximal excess energy $[\mathrm{M}]^{+}$.

As a result of two additional symmetrical detachments of fluorine atoms in the N1 series, as well as two or four additional detachments of fluorine atoms in the N3 series, alkenyl subseries of $\mathrm{N} 1 *, \mathrm{~N} 3^{*}$ and $\mathrm{N} 3{ }^{* *}$ ions are formed, the occurrence of which is a result of additional stabilization of primary ions of series $\mathrm{N} 1$ and N3. The probability of formation the N1* series formation, increases in devices with an ion trap, in case of extended presence of ions at the separation zone.

Separations of three, five and seven fluorine atoms, subsequent emissions of $\mathrm{CF}_{2}$, mass values of intermediate $\left(\mathrm{CF}_{2}\right)_{3} \mathrm{~N}$ and final $\mathrm{CF}_{2}-\mathrm{N}_{-} \mathrm{CF}_{2}, \mathrm{CF}=\mathrm{N}=\mathrm{CF}$ nitrogen-containing ions, allow us to conclude that perfluorotributylamine fragmentation occurs by symmetric detachments of fluorine atoms and emission of $\mathrm{CF}_{2}$ groups, with the preferred conservation of the symmetry of the formed ions.

Tertiary perfluoroamines with three substituents of different masses, are fragmented similarly to PFTBA, however, the sequence of detachments depends on the mass of substituents. The rule is, that the detachment of a nitrogen-containing radical NR"R"', with the lowest mass substituents, leads to formation of a perfluoroalkyl ion $\left[R^{\prime}\right]^{+}$with the maximum mass of the substituent, and the separation of the maximum mass substituent $\mathrm{R}^{\prime}$ without one $\mathrm{CF}_{2}$ group, that is, the radical $\left[\mathrm{R}^{\prime}-\mathrm{CF}_{2}\right]$ to the formation of the nitrogen-containing ion $\left[\mathrm{R}^{\prime \prime} \mathrm{R} " \mathrm{NCF}_{2}\right]^{+}$with substituents having minimal masses. Thus, the fragmentation of tertiary perfluoroamines with three substituents of different masses also shows a tendency towards an increase in the symmetrization of the formed ions.

\section{Acknowledgments}

This work was supported by Ministry of Science and Higher Education of Russian Federation using scientific equipment of Molecules Structure Study Center of INEOS RAS.

\section{Literature}

1. Iida Yoshi, Okada Shizuko, Seikei Daigaku Kogakubu Hokoku, 1984, 37, 2453-2454.

2. Brilis, George Michael, Brumley, William C, Analytica Chemica Acta, 1990, 229(2), 163-8.

3. Hvistendahl G., Undheim K., Org. Mass. Spectrom., 1970, 3, 821.

4. Zahorszky, U.I., Organic Mass Spectrometry, 1979, 14(2), 66-74.

5. Kagramanov N.D., Fluorine notes, 2020, 1 (128), 3-4. 